\title{
Changes in climate and changing climate regions in Slovakia
}

\author{
Lívia LABUDOVÁ a *, Pavol FAŠKO ${ }^{\text {b }}$, Gabriela IVAŇÁKOVÁ b
}

\begin{abstract}
In the context of climate change, scientists discuss the relevant reference periods for the assessment of changes in climate. Recently, many studies have been published comparing recent conditions with the last reference period 1961-1990. In this paper, the trends of annual, seasonal and monthly average air temperature, as well as annual, seasonal and monthly precipitation totals in Slovakia, are presented to point out changes which will probably show up in the next reference period 1991-2020. In the second part of paper, changes in the climate regions in Slovakia are analysed, comparing spatial distributions in the period 1961-1990 and in the period 1961-2010.
\end{abstract}

Keywords: temperature, precipitation, trend analysis, climate regions, Konček's climate classification, Slovakia

\section{Introduction}

The trends of meteorological variables in the context of climate change are of high interest in current climate research. Since the 1980s, many such studies have been published world-wide. Some of this research has dealt with climate changes in Central Europe.

CARPATCLIM, a complex research project focused on climate analysis in the Carpathian region, was active in the years 2010-2013 and used gridded data with a horizontal resolution $0.1^{\circ} \times 0.1^{\circ}$, which were obtained from observational data in the period 1961-2010 using interpolation methods. Considering the whole region, annual precipitation was reported as positive anomalies in the 1960s and the 1970s, negative anomalies in the 1980 s and positive anomalies again after 1995 . The results showed that altitude plays an important role in the trends of climatic variables. In the Carpathian Mountains less significant trends were observed than in surrounding areas, especially in spring and summer. A positive significant trend in annual precipitation was observed across the borders between Slovakia and Czech Republic and between Romania and Ukraine (Spinoni et al., 2014; Cheval et al., 2014). On the other hand, the trend of maximum, minimum and average temperatures increased on an annual scale and in all seasons, except autumn. Only over the Carpathian Mountains did the maximum air temperature in summer record no significant trend (Cheval et al., 2014).

More studies were focused on a single country. Hundecha and Bárdossy (2005) identified the $90^{\text {th }}$ percentile daily maximum and the $10^{\text {th }}$ percentile daily minimum temperatures as showing increasing trends (except autumn) for the majority of station-based datasets in south-west Germany, and many of them were significant. The highest average increase in the $90^{\text {th }}$ percentile daily maximum temperature was observed in winter: $+2.7^{\circ} \mathrm{C}$ in the period 1958-2001. The fact that extreme daily minimum temperature is increasingly less extreme was confirmed by the decreasing number of frost days. On the other hand, extreme heavy precipitation became even more extreme, both in terms of magnitude and frequency, in winter and in the transition seasons. The increase of air temperature during the second half of the $20^{\text {th }}$ century was also observed for 146-year observational data in Poland. But the totals and the frequency of winter precipitation increased in Krakow in the period 1863-2008, while annual precipitation decreased in lowland regions (Twardosz et al., 2012). On the contrary, Niedzwiedz et al. (2009) identified no trend in precipitation, using long-term datasets from the seven oldest meteorological stations in Central Europe. Primarily, such differences are explained by the high variability of precipitation in this region.

Several studies have been published in the Czech Republic (e.g. Brázdil et al., 1995; Pišoft et al., 2004; Brázdil et al., 2009; Brázdil et al., 2012). The analysis of gridded Czech temperature series using wavelet transformations demonstrated an increasing trend in air temperature during the last century (Pišoft et al., 2004). It was noted that the warming tendency in Prague started ca. 1850 and in Brno at the end of the $19^{\text {th }}$ century, using long-term observational data. An important acceleration of temperature increase was confirmed from the 1970s by Brázdil et al. (2012), with one exceptionally cold year in 1996 (Brázdil et al., 2009). Most of the other selected stations observed no significant trends in precipitation, which is in agreement with previous studies (Brázdil et al., 2009; Brázdil et al., 2012).

Since the late $1990 \mathrm{~s}$, most studies dealing with air temperature and precipitation were focused on the comparison of observational data with climate scenarios from climate models, but information about the trends of some studied climatic variables can be found, as well. In Slovakia, according to Lapin and Melo (1999), precipitation decreased significantly, mostly in the south west in the warm half-year, but average air temperature and evapotranspiration increased significantly in their study period from 1881 to 1998 . The highest increase was observed in the months from January to August. A comparable

\footnotetext{
a Department of Physical Geography and Geoecology, Faculty of Natural Sciences, Comenius University in Bratislava, Bratislava, Slovakia (*corresponding author: L. Labudová, e-mail: livia.labudova@gmail.com)

${ }^{\mathrm{b}}$ Slovak Hydrometeorological Institute, Bratislava, Slovakia
} 
evolution in the future was expected according to the results of the Canadian coupled GCM model, which was downscaled for the territory of Slovakia. These trends were replicated at the meteorological station at Hurbanovo in later studies by Melo et al. (2007a) and Pecho et al. (2008). The average annual air temperature in Hurbanovo increased about $1.4^{\circ} \mathrm{C}$ in the period 1871-2006 (Melo et al., 2007b). This change resulted in the first occurrence of a very dry climate region, according to Konček's climate classification from the period 1951-1980. This classification was established by Konček and Petrovič (1957) and is described below.

The drying trends in the Danubian lowlands during the entire $20^{\text {th }}$ century were also confirmed by Pecho et al. (2008), Melo et al. (2007b) and Lapin et al. (2009). The shift in climate conditions towards the climate of southern regions (e.g. Hungary) can be shown by changes in the occurrence of insect species in south-western Slovakia. Significant changes in Hurbanovo occurred also in the number of days with an average air temperature below or equal to $0{ }^{\circ} \mathrm{C}$. This value significantly decreased in the period 1901-2006, while the number of days with average air temperatures $\geq 15^{\circ} \mathrm{C}$ and $\geq 20^{\circ} \mathrm{C}$ significantly increased (Melo et al., 2007b).

According to Faško et al. (2009), nearly all GCMs downscaled for Slovakia in the period 1991-1995 recorded only small increases in annual precipitation totals. No change, or even some decrease, was expected only in the southern lowlands. The highest increase in precipitation totals was expected in winter and in the mountainous northern part of Slovakia (up to $30 \%$ ). Summer precipitation seemed to be very irregular (more frequent drought spells and flooding events) in the future, and winter precipitation seemed to occur mostly as rain up to $800 \mathrm{~m}$ a.s.l. Newer regional climate models were used in Lapin and Melo (2012).

In the context of climate change, scientists discuss the attribution of reference periods to the assessment of climate. Recently, many studies have been published comparing recent conditions with the last reference period 1961-1990. In this paper, the trend of annual, seasonal and monthly average air temperature, as well as annual, seasonal and monthly precipitation in Slovakia, is presented to record changes which could probably be shown in the next reference period 1991-2020. The first GCM was used in Slovakia in 1991 (quite late in comparison to western countries), and some other GCMs at the end of the 1990s and at the beginning of $2000 \mathrm{~s}$. At present, then, we can partly verify if their trend projections for the beginning of $21^{\text {st }}$ century were correct. Additionally, this paper shows that the reference periods did not show such differences in the past as will probably be forthcoming, in comparing the reference periods 1961-1990 and 1991-2020. Changes in temperature and precipitation in different regions, not only the lowlands but also the high mountains, result in the changes of climate regions in Slovakia. Some climate regions in Slovakia demonstrate some significant changes as presented in this paper. Such changes should support the existence of climate change in this region as these changes are sometimes still disputed.

\section{Methods}

\subsection{Temperature and precipitation data}

This study was prepared using average monthly air temperature and monthly precipitation totals from 14 meteorological stations in Slovakia (Fig. 1) over the period 1931-2014. The selection of the stations was conditioned by complete observed datasets in the database of the Slovak Hydrometeorological Insitute. The only exception was the station Lomnický štít peak, which had missing data from January 1931 to September 1940 and in the years 1945 and 1946. The data from the database, from the publications Zborník prác SHMÚ Nr. 23 (Petrovič and Šoltís, 1984) and Klíma Tatier (Konček, 1974), were homogenized and missing values were imputed using the software MASHv3.03 (Szentimerey, 2003). This process resulted in a dataset without discontinuities, some of which occurred due to the moving of stations, changes of observers, or changes in station equipment, etc.

The selected meteorological stations represent lowland, valley and mountainous parts of the country. After homogenisation, the data were analysed on monthly, seasonal and annual time scales. The spatial average temperature values for all of Slovakia were calculated as averages from 11 stations with weight 1 and from three stations with weight 0.1 (mountainous stations Lomnický štít peak, Štrbské pleso lake and Skalnaté pleso lake). This method corresponds with the established calculation of spatial average temperature in Slovakia (Lapin et al., 1995). The linear model was used for trend analysis. The significance

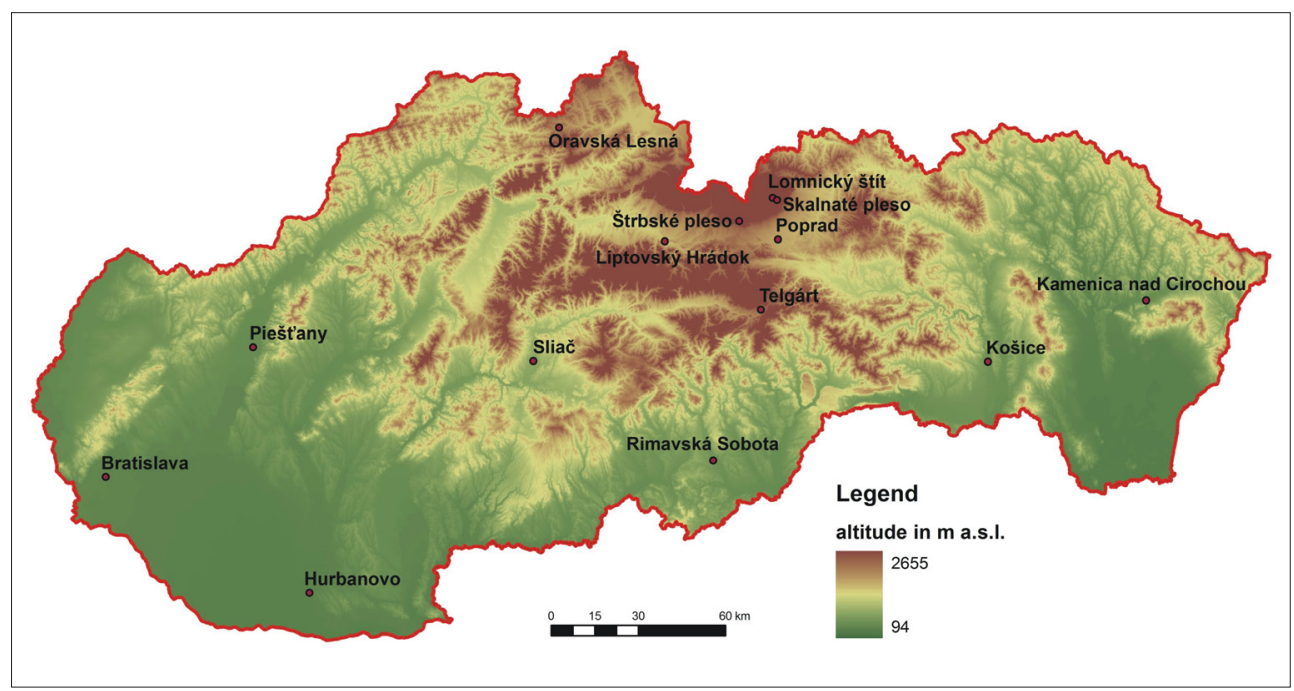

Fig. 1: Location of selected meteorological stations in Slovakia.

Source: authors, digital terrain model by Slovak Environment Agency 
of the trend was tested using F-statistics at significance level $\alpha=0.05$. To demonstrate not only changes in average air temperature, but also in its maximum and minimum, the occurrence of "summer" and "tropical" days in the spring months was determined, as well as the occurrence of "ice"and "arctic" days in winter months. A "summer" day is defined in the official Meteorological dictionary (Sobíšek, 1993) as a day with a maximum daily temperature greater than or equal to $25^{\circ} \mathrm{C}$. The definition of "tropical" day is very similar, but the temperature threshold is set at $30^{\circ} \mathrm{C}$. The "ice" day occurs when the maximum daily temperature is less than $0{ }^{\circ} \mathrm{C}$ and, similarly with respect to a threshold, a maximum daily temperature below $-10^{\circ} \mathrm{C}$ denotes the occurrence of an "arctic" day.

The spatial average precipitation totals can be used to characterize precipitation conditions in a selected region. This value was obtained from precipitation data for each station using a double weighted average method. The result was the dataset of spatial monthly precipitation totals for the entire country. It represents a quite conservative value, which is proper for the analysis of precipitation trends (Šamaj and Valovič, 1982). The data for each station were analysed on monthly, seasonal and annual time scales. Again, the linear model was used for trend analysis. The significance of the trend was tested using F-statistics with the significance level $\alpha=0.05$.

The long-term characteristics of meteorological variables, including averages for the reference periods, comprise basic research activities in climatology. The reference period is defined as a 30-year dataset of meteorological observations. The World Meteorological Organisation (WMO) established the reference periods 1901-1930, 1931-1960 and 1961-1990. Such defined conditions enable comparisons at larger regional scales, to quantify changes in meteorological variables, and to objectively assess the recent status of the climate.

\subsection{Classification of the climate regions in Slovakia following Konček and Petrovič (1957)}

Slovakia can be characterised as a very complex landscape, which can result in different climate conditions within a small area. On the other hand, it was not possible to use methods for clapssification of large areas, because they were too coarse for the area of the country Czechoslovakia as then defined. Therefore, Konček and Petrovič (1957) established a new classification of the climate regions of Czechoslovakia. The classification consists of three main regions - warm, moderately warm and cold regions. They tested many different criteria based on continentality and temperature characteristics, e.g. average annual temperature amplitude, the ratio between months with maximum and minimum precipitation, cumulative temperature sums for periods with average daily temperature above $5{ }^{\circ} \mathrm{C}, 10^{\circ} \mathrm{C}$ or $15^{\circ} \mathrm{C}$. These characteristics have been shown to be inappropriate or bringing no new information other than isolines representing the number of summer days. This characteristic differentiates regions with different continentality quite well, as continentality is caused by different factors in the Czech Republic and in Slovakia (Konček and Petrovič, 1957).

Additionally, the isoline of 50 and more summer days corresponds to isoline bounding region with the first harvest day of winter rye till $15^{\text {th }}$ July. Therefore, it was established as a threshold isoline for a warm climate region, where the production of warmth-requiring crops (e.g. maize or tobacco) is possible. Another very important characteristic was the isoline of average temperature in July equal to $16{ }^{\circ} \mathrm{C}$, which is located approximately at the same altitude (700 $\mathrm{m}$ a.s.l.) in the whole country. Spring is quite short in areas up to this isoline and late frosts occur quite often. For this reason only the production of less warmth-requiring crops is suitable in this area. Therefore, the isoline of average temperature in July equal to $16{ }^{\circ} \mathrm{C}$ was set as the upper threshold of moderately-warm climate regions. The rest of country is allocated to the cold climate region.

Each region has several sub-regions, which are further classified according to average temperatures in January and July, as well as Konček's moisture index and altitude (Tab. 1).

Konček's moisture index is an empirical estimate of the water balance in the warm half-year (April-September). It is estimated according to the equation:

$$
\mathrm{I}_{\mathrm{z}}=1 / 2 \mathrm{R}+\Delta r-10 \times T-\left(30+\mathrm{v}^{2}\right)
$$

where

$\mathrm{I}_{\mathrm{z}}=$ Konček's moisture index, $\mathrm{R}=$ precipitation total in warm half-year (WH), $\Delta r=$ precipitation surplus above $105 \mathrm{~mm}$ in winter, $T=$ average temperature in $\mathrm{WH}$; and $v=$ average wind speed measured at 2 p.m. in WH.

The advantage of this index is primarily in considering precipitation in the warm half-year, which is the most important for vegetation as the months from April to September comprise almost the entire growing season. The authors assumed that half of the total precipitation in this period is evaporated and the rest results in run-off. The index also considers winter precipitation, but only its surplus, which improves water balance at the beginning of the growing season. The threshold $(105 \mathrm{~mm})$ represents the amount which is usually run-off or evaporated in March and hence cannot support the water balance in April (Konček and Petrovič, 1957). This index provides very similar information about moisture conditions to those reached using Thornthwaite's moisture index (Thornthwaite, 1948).

The differences in average winter temperature throughout the country are very clear. They led to the establishment of average temperature in January $\left(\mathrm{T}_{\mathrm{Jan}}\right.$ ) as another criterion for the sub-division of sub-regions. Another important criterion is altitude, which plays an important role in the regime of climatic variables. The last characteristic, dividing sub-regions in the cold climate region, is again average temperature in July ( $\left.\mathrm{T}_{\text {July }}\right)$. The production of oats is possible in areas up to an isoline of $\mathrm{T}_{\text {July }}$ equal to $12{ }^{\circ} \mathrm{C}$. This sub-region is described as moderately cold. The isoline of $\mathrm{T}_{\text {July }}$ equal to $10{ }^{\circ} \mathrm{C}$ represents the upper threshold of forest and this sub-region is described as cold mountainous. Above this isoline are areas of alpine meadows and rocks. This classification describes in strong detail various climate differences in Slovakia, where one can find regions from semi-steppe to precipitation-very rich areas, as well as from warm areas to cold areas, where the growth of vegetation is not possible.

This moisture index was used in the original methodology of land evaluation units, which describe units with similar climatic and soil features. The index, however, is not so well suited for operational monitoring, but it reflects climate changes quite well (e.g. Melo, Kružicová, 2011; Melo et al., 2007a). This classification was used in the Landscape Atlas of the Slovak Republic (2002). In this paper, we compare the results of a climate classification in the period 1961-1990, published in Landscape Atlas of 


\begin{tabular}{|c|c|c|}
\hline & Sub-region & Climate conditions \\
\hline \multicolumn{3}{|c|}{ Warm region (50 or more summer days per year) } \\
\hline $\mathrm{T} 1$ & warm, very dry, with mild winter & $\mathrm{T}_{\text {Jan }}>-3{ }^{\circ} \mathrm{C}, \mathrm{I}_{\mathrm{z}}<-40$ \\
\hline $\mathrm{T} 2$ & warm, dry, with mild winter & $\mathrm{T}_{\mathrm{Jan}}>-3^{\circ} \mathrm{C},-20>\mathrm{I}_{\mathrm{z}} \geq-40$ \\
\hline $\mathrm{T} 3$ & warm, dry, with cold winter & $\mathrm{T}_{\text {Jan }} \leq-3{ }^{\circ} \mathrm{C},-20>\mathrm{I}_{\mathrm{z}} \geq-40$ \\
\hline $\mathrm{T} 4$ & warm, moderately dry, with mild winter & $\mathrm{T}_{\text {Jan }}>-3^{\circ} \mathrm{C}, 0>\mathrm{I}_{\mathrm{z}} \geq-20$ \\
\hline $\mathrm{T} 5$ & warm, moderately dry, with cold winter & $\mathrm{T}_{\mathrm{Jan}} \leq-3^{\circ} \mathrm{C}, 0>\mathrm{I}_{\mathrm{z}} \geq-20$ \\
\hline $\mathrm{T} 6$ & warm, moderately humid, with mild winter & $\mathrm{T}_{\mathrm{Jan}}>-3^{\circ} \mathrm{C}, 60>\mathrm{I}_{\mathrm{z}} \geq 0$ \\
\hline $\mathrm{T} 7$ & warm, moderately humid, with cold winter & $\mathrm{T}_{\text {Jan }} \leq-3^{\circ} \mathrm{C}, 60>\mathrm{I}_{\mathrm{z}} \geq 0$ \\
\hline $\mathrm{T} 8$ & warm, humid, with mild winter & $\mathrm{T}_{\text {Jan }}>-3^{\circ} \mathrm{C}, 120>\mathrm{I}_{\mathrm{z}} \geq 60$ \\
\hline T9 & warm, humid, with cold winter & $\mathrm{T}_{\mathrm{Jan}} \leq-3^{\circ} \mathrm{C}, 120>\mathrm{I}_{\mathrm{z}} \geq 60$ \\
\hline \multicolumn{3}{|c|}{ Moderately warm region (less than 50 summer days per year and $16^{\circ} \mathrm{C} \leq T_{\text {July) }}$} \\
\hline M1 & moderately warm, moderately humid, with mild winter, upland & $\mathrm{T}_{\text {Jan }}>-3^{\circ} \mathrm{C}, 60>\mathrm{I}_{\mathrm{z}} \geq 0$, altitude $\leq 500$ m a.s.l. \\
\hline M2 & moderately warm, moderately humid, with very cold winter, valley/basin & $\mathrm{T}_{\mathrm{Jan}} \leq-5^{\circ} \mathrm{C}, 60>\mathrm{I}_{\mathrm{z}} \geq 0$ \\
\hline M3 & moderately warm, moderately humid, upland to highlands & $-5^{\circ} \mathrm{C}<\mathrm{T}_{\mathrm{Jan}} \leq-3{ }^{\circ} \mathrm{C}, 60>\mathrm{I}_{\mathrm{z}} \geq 0$ \\
\hline M4 & moderately warm, humid, with mild winter, upland to planes & $\mathrm{T}_{\mathrm{Jan}}>-3^{\circ} \mathrm{C}, 120>\mathrm{I}_{\mathrm{z}} \geq 60$ \\
\hline M5 & moderately warm, humid, with cold to very cold winter, valley/basin & $\mathrm{T}_{\mathrm{Jan}} \leq-3^{\circ} \mathrm{C}, 120>\mathrm{I}_{\mathrm{z}} \geq 60$, altitude $\leq 500 \mathrm{~m}$ a.s.l. \\
\hline M6 & moderately warm, humid, highlands & $\mathrm{T}_{\text {Jan }} \leq-3^{\circ} \mathrm{C}, 120>\mathrm{I}_{\mathrm{z}} \geq 60$, altitude $>500$ m a.s.l. \\
\hline M7 & moderately warm, very humid, highlands & $\mathrm{I}_{\mathrm{z}} \geq 120$ \\
\hline \multicolumn{3}{|c|}{ Cold region $\left(T_{\text {July }}<16^{\circ} \mathrm{C}\right)$} \\
\hline $\mathrm{C} 1$ & moderately cold & $12^{\circ} \mathrm{C} \leq \mathrm{T}_{\text {July }}<16^{\circ} \mathrm{C}$ \\
\hline $\mathrm{C} 2$ & cold mountainous & $10^{\circ} \mathrm{C} \leq \mathrm{T}_{\text {July }}<12^{\circ} \mathrm{C}$ \\
\hline $\mathrm{C} 3$ & very cold mountainous & $\mathrm{T}_{\mathrm{July}}<10^{\circ} \mathrm{C}$ \\
\hline
\end{tabular}

Tab. 1: The classification of climate regions in Slovakia

Source: Landscape Atlas of the Slovak Republic (2002), re-worked by authors

the Slovak Republic (2002), with the results of our updated classification, which is published in the Climate Atlas of the Slovak Republic (2015)

\section{Results}

\subsection{Temperature trends}

The period 1991 to 2014 is characterised by an increasing trend of air temperature characteristics. In Slovakia most of the trend analyses in recent years were carried out and published for single meteorological stations separately. In this paper, the motivation was to determine if the significant increasing trend is comparable for the entire territory.

Climate conditions in Slovakia are very complex due to the higher oceanicity in the western part, but higher continentality in the eastern part of the country. Climate contrasts exist also in the north-south direction, as colder climate dominates in the north and warmer climate in the south. Despite these differences within a fairly small area, a comparable increasing trend in annual air temperature is recorded in the dataset of each station. The average annual air temperature increased in the period 1991-2014 from about $0.9^{\circ} \mathrm{C}$ (e.g. in Pieštany, Lomnický štít, Skalnaté pleso, Kamenica nad Cirochou, Telgárt, Sliač, Rimavská Sobota, Oravská Lesná) to $1.1^{\circ} \mathrm{C}$ in Bratislava, Košice and Liptovský Hrádok, in comparison to its average value in the period 1961-1990. On the other hand, a difference only $0.1^{\circ} \mathrm{C}$ was reached comparing average annual air temperature in the periods 1931-1960 and 1961-1990. Thus, the total increase in the whole study period reached at least $1^{\circ} \mathrm{C}$.

These results are confirmed by the spatial average value of annual air temperatures for the whole of Slovakia. It reached an increase of about $1^{\circ} \mathrm{C}$ in the period 1991-2014 compared to its average value in the period 1961-1990 (Fig. 2).

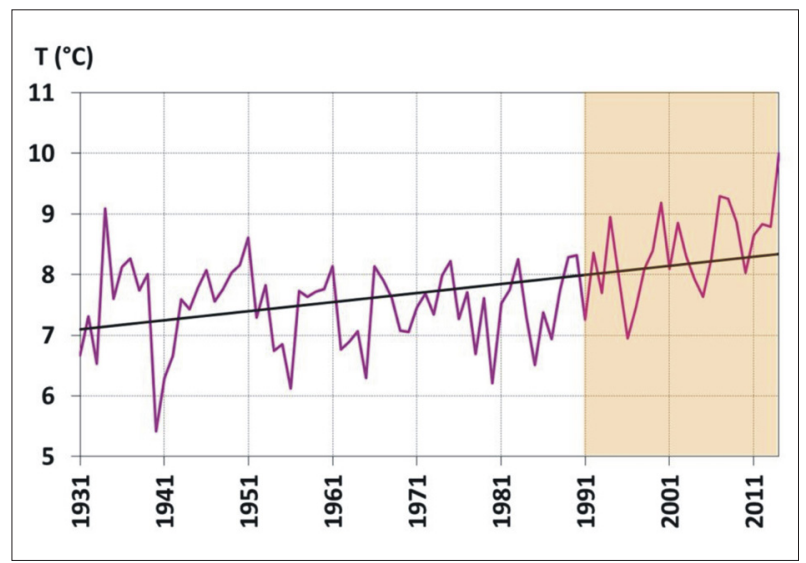

Fig. 2: Spatial average annual temperature in Slovakia in the period 1931-2014. Source: authors 
Considering spatial average monthly air temperatures, the increasing trend of average monthly temperature in each month reveal different intensities. The highest increase was observed in the months of January, June, July and August (Tab. 2). The trend in all these months is statistically significant. The spatial value of average monthly air temperature increased about $1.5^{\circ} \mathrm{C}$ in January and June and about $1.7^{\circ} \mathrm{C}$ in July and August, comparing the periods 1961-1990 and 1991-2014. But comparing the periods 1931-1960 and 1961-1990, the increase reached at most $0.6{ }^{\circ} \mathrm{C}$ in July.

Similar trends are recorded in the months of the transitional seasons and in December, but they are not as evident as those mentioned above, except March, April and May (Fig. 3). Most of them are statistically insignificant, again except March, April and May. The differences between the average for 1961-1990 and the average for 1991-2014 reached at most $0.6^{\circ} \mathrm{C}$.

The significant increasing trend in April can be explained by the shorter snow cover duration and its smaller spatial extent in March (Pecho et al., 2010a). This situation enables faster warming processes at the surface, which results in higher air temperatures in the second half of spring. A comparable trend was observed in May. There are several known cases when short periods with maximum daily air temperatures above or equal to $30^{\circ} \mathrm{C}$ were recorded at the beginning of May (Fig. 4). Their occurrence has been noted several times since the last decade of the $20^{\text {th }}$ century. Such cases were very rare in the past and they referred to single days.

Recently, short episodic heat waves, or single heat days have been recorded even at the end of April. They occurred frequently in Slovakia at the beginning of the 2010s (Výberči, 2012). A good example is the number of summer $\left(\mathrm{T}_{\max } \geq 25^{\circ} \mathrm{C}\right)$ and tropical days $\left(\mathrm{T}_{\max } \geq 30{ }^{\circ} \mathrm{C}\right)$ in Hurbanovo. The increase of tropical days since the last decade of 20th century is most evident in May (Fig.4). In the case of summer days, it is interesting to note that they are recorded more often in May months, when the maximum temperature was higher than $25^{\circ} \mathrm{C}$ during more than one half of its days. Since 1991, five of such May months have occurred (in the years 1993, 2000, 2001, 2003 and 2012), while such a case was noted only once (in 1958) during the previous sixty years (1931-1990). This trend was most notable in Bratislava, where monthly average temperatures in April increased about $1.3^{\circ} \mathrm{C}$ when compared to the periods 1961-1990 and 1991-2014. It is an incomparably higher increase than at Lomnický štít peak, where the difference reached "only" $0.8^{\circ} \mathrm{C}$ (Fig. 5).

The increase at Lomnický štít peak was only slightly higher in May, when it reached the value of $0.9^{\circ} \mathrm{C}$. But the difference, compared to the previously-mentioned periods, is much higher when considering the summer months, as average monthly temperatures in July and August increased about $1.8^{\circ} \mathrm{C}$ and $1.6{ }^{\circ} \mathrm{C}$, respectively. Such values were also observed in the lowland parts of Slovakia. It appears from this finding that snow cover impacts as a barrier during spring warming not only in the lowlands, but also in mountainous regions (Pecho et al., 2010b). When the snow cover is missing, the warming has the same intensity as that found in the lower parts of country (Fig. 6).

With respect to the highest parts of Slovakia, the warming acceleration is higher than in the lowlands, when assessing the warming dynamic over the last 25 years. This warming process began in the lowlands in the 1990s, but it occurred with some delay in high mountainous regions in the 2000s and 2010s. Besides circulation factors, this trend demonstrates that the lowest parts of the atmosphere are warmed from the surface first, and the warmth is then transported into higher levels of the atmosphere through atmospheric processes (Matejovič, 2011).

At the beginning of the period 1991-2014, record temperatures (temperature exceeding the highest observed value) were concentrated in the southwestern part of Slovakia. Recently, they have occurred in northern and eastern regions. It is interesting to note that their occurrence

\begin{tabular}{|c|c|c|c|c|c|c|c|c|c|c|c|c|c|c|c|c|c|}
\hline Station & I & II & III & IV & V & VI & VII & VIII & IX & $\mathbf{X}$ & XI & XII & 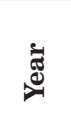 & 茪 & $\begin{array}{l}\dot{\Phi} \\
\text { ڤ్ }\end{array}$ & 志 & 离 \\
\hline Bratislava-Letisko & .36 & 0.23 & 0.25 & 0.19 & 0.16 & 0.18 & 0.18 & 0.19 & 0.00 & 0.08 & 0.09 & 0.10 & 0.17 & 0.20 & 0.18 & 0.06 & 0.23 \\
\hline Liptovský Hrádok & 0.38 & 0.29 & 0.24 & 0.18 & 0.16 & 0.20 & 0.18 & 0.18 & -0.03 & 0.12 & 0.12 & 0.13 & 0.18 & 0.19 & 0.19 & 0.07 & 0.27 \\
\hline Hurbanovo & 0.37 & 0.26 & 0.25 & 0.21 & 0.16 & 0.13 & 0.15 & 0.15 & -0.02 & 0.08 & 0.10 & 0.11 & 0.17 & 0.21 & 0.14 & 0.06 & 0.25 \\
\hline Kamenica n/C. & 0.38 & 0.21 & 0.24 & 0.19 & 0.12 & 0.13 & 0.17 & 0.15 & -0.03 & 0.07 & 0.06 & 0.04 & 0.15 & 0.18 & 0.15 & 0.03 & 0.22 \\
\hline Košice-Letisko & 0.32 & 0.23 & 0.25 & 0.23 & 0.15 & 0.17 & 0.21 & 0.18 & 0.02 & 0.09 & 0.08 & 0.00 & 0.16 & 0.21 & 0.19 & 0.06 & 0.18 \\
\hline Lomnický Štít & 0.23 & 0.14 & 0.05 & 0.15 & 0.14 & 0.12 & 0.17 & 0.18 & -0.02 & 0.09 & 0.11 & 0.08 & 0.12 & 0.11 & 0.15 & 0.06 & 0.15 \\
\hline Oravská Lesná & 0.38 & 0.22 & 0.19 & 0.16 & 0.15 & 0.13 & 0.16 & 0.15 & -0.04 & 0.06 & 0.10 & 0.02 & 0.14 & 0.16 & 0.14 & 0.04 & 0.21 \\
\hline Pieštany & 0.27 & 0.16 & 0.20 & 0.14 & 0.12 & 0.10 & 0.14 & 0.17 & -0.03 & 0.06 & 0.06 & 0.06 & 0.12 & 0.15 & 0.14 & 0.03 & 0.16 \\
\hline Poprad & 0.39 & 0.20 & 0.23 & 0.19 & 0.12 & 0.14 & 0.16 & 0.19 & -0.05 & 0.06 & 0.09 & 0.07 & 0.15 & 0.18 & 0.16 & 0.03 & 0.21 \\
\hline Rimavská Sobota & 0.37 & 0.23 & 0.20 & 0.21 & 0.15 & 0.16 & 0.17 & 0.21 & -0.04 & 0.09 & 0.04 & 0.09 & 0.16 & 0.19 & 0.18 & 0.03 & 0.23 \\
\hline Skalnaté Pleso & 0.29 & 0.19 & 0.13 & 0.22 & 0.18 & 0.14 & 0.19 & 0.17 & -0.01 & 0.15 & 0.16 & 0.15 & 0.16 & 0.18 & 0.16 & 0.10 & 0.22 \\
\hline Sliač & 0.35 & 0.18 & 0.18 & 0.20 & 0.17 & 0.15 & 0.14 & 0.18 & -0.01 & 0.08 & 0.07 & 0.02 & 0.14 & 0.18 & 0.16 & 0.04 & 0.18 \\
\hline Štrbské Pleso & 0.31 & 0.25 & 0.15 & 0.20 & 0.19 & 0.14 & 0.17 & 0.19 & -0.02 & 0.10 & 0.10 & 0.08 & 0.16 & 0.18 & 0.17 & 0.06 & 0.22 \\
\hline Telgárt & 0.31 & 0.20 & 0.20 & 0.18 & 0.11 & 0.12 & 0.16 & 0.16 & -0.07 & 0.04 & 0.10 & 0.01 & 0.13 & 0.16 & 0.15 & 0.03 & 0.18 \\
\hline Slovakia & 0.35 & 0.22 & 0.22 & 0.19 & 0.14 & 0.15 & 0.17 & 0.17 & -0.03 & 0.08 & 0.08 & 0.06 & 0.15 & 0.18 & 0.16 & 0.04 & 0.21 \\
\hline
\end{tabular}

Tab. 2: Increase of average monthly, seasonal and annual temperature in ${ }^{\circ} \mathrm{C}$ per decade in the period 1931-2014 (bold values are statistically significant). Source: authors 


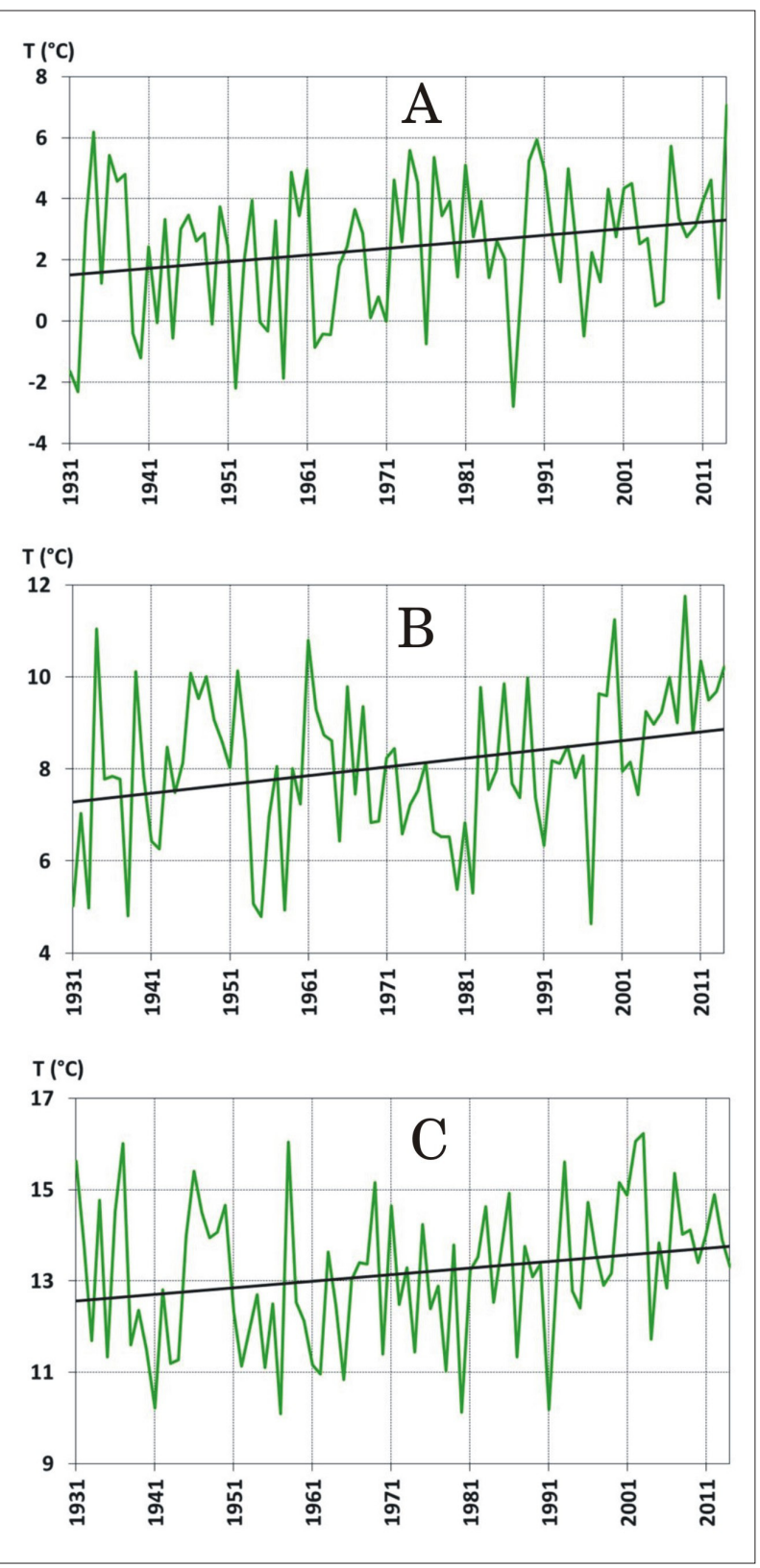

Fig: 3: Spatial average value of monthly temperature in March to May (A to C) in Slovakia in the period 1931-2014. Source: authors

is higher there than in the traditionally warmer southwestern part of country. Due to this, the area with occurrence of record temperatures has become less heterogeneous. To some degree, one notes a parallel to temperature changes in mountainous areas, but in this case we can speak about latitudinal zonality.

The different intensities of increasing trends in each month result in similar differences in each season and in the warm and cold half-years. Only a small increase is observed in autumn due to the slow increasing trend in the months September and October, probably due to large-scale circulation over Europe. Spring shows only a slightly higher trend in average temperatures than autumn; nevertheless, the increasing trend in April and May is high. It is balanced out by only a low trend in March at some stations. There is a similar situation in winter, when the trend in January is as high as in the summer months, but the months of December and February show only a low increasing trend. Similar impacts are expressed in the number of ice $\left(\mathrm{T}_{\max } \leq 0^{\circ} \mathrm{C}\right)$ and arctic days $\left(\mathrm{T}_{\max } \leq-10^{\circ} \mathrm{C}\right)$, which decreased the most clearly in January in Hurbanovo. The last arctic day in Hurbanovo was recorded in 1987.

These findings are in very good agreement with meteorological experiences at the end of the $20^{\text {th }}$ century and at the beginning of the $21^{\text {st }}$ century (Faško et al., 2013). The transitional seasons are not very outstanding. On the other hand, it is unusually warm at those times when winter should be ending. The notable results are the changes from late summer into winter weather in a short time period during autumn. Similar changes are recorded during spring, when winter weather at the end of March and the beginning of April turns into summer weather in the second part of April (Pecho et al., 2010a).

The most notable increasing trend is observed in the summer for the whole country. The difference, in comparison to other seasons, reached $+1^{\circ} \mathrm{C}$, considering spatial average values. The same dominant trend is visible comparing warm and cold half-years (Fig. 7). All months with the highest increasing trend of average monthly temperatures (April, May, June, July and August) are concentrated in the warm half-year, while comparable trends in the cold half-year are identified only in January.

\subsection{Precipitation trends}

With respect to air temperature trends since 1931, it is also interesting to identify precipitation trends. Differences between air temperature and precipitation as meteorological variables are commonly known. Research on precipitation is more difficult in this sense, whether considering an annual or other periodic regime, as well as its spatial distribution.

The long-term averages of spatial precipitation totals for the reference periods show only small changes in each month, season, half-year and year, opposite to the temperature trends. The only exception is the month of July, even though it is not statistically significant.

In the $1990 \mathrm{~s}$ and $2000 \mathrm{~s}$, some notable precipitation weather conditions were recorded, which resulted in floods. It is probable, as well, that an important role was played by a greater spatial extent of rain storms and their intensity, which caused flash floods (Faško et al., 2006).

Differences between the reference periods, or longterm precipitation averages for each station, represent some specifics. They are conditioned by the location of the meteorological station with respect to the air masses bringing precipitation, but also by the enhancing or the weakening of the precipitation significance of these masses, respectively (Lapin et al., 1995). These conditions resulted in increased precipitation totals in the months from January to March in the period 1991-2014 in northwest Slovakia (Fig. 8), when compared to the reference periods 1931-1960 and 1961-1990. The increasing trend in these months is higher than in July. Although the increasing trend in winter precipitation is not statistically significant, the highest increase was recorded at high altitudes. These results are in good agreement with Cheval et al. (2014). The higher precipitation totals in these months were not caused just by humid air masses from the northwest, as temperature conditions in this region were important as well (Lapin, 2015). For example, winters after 1991 were not as cold as in the past, which resulted more often in the occurrence of mixed and liquid precipitation (Pecho et al., 2009). The higher temperatures in the period from January to March also supported the higher precipitation totals. 


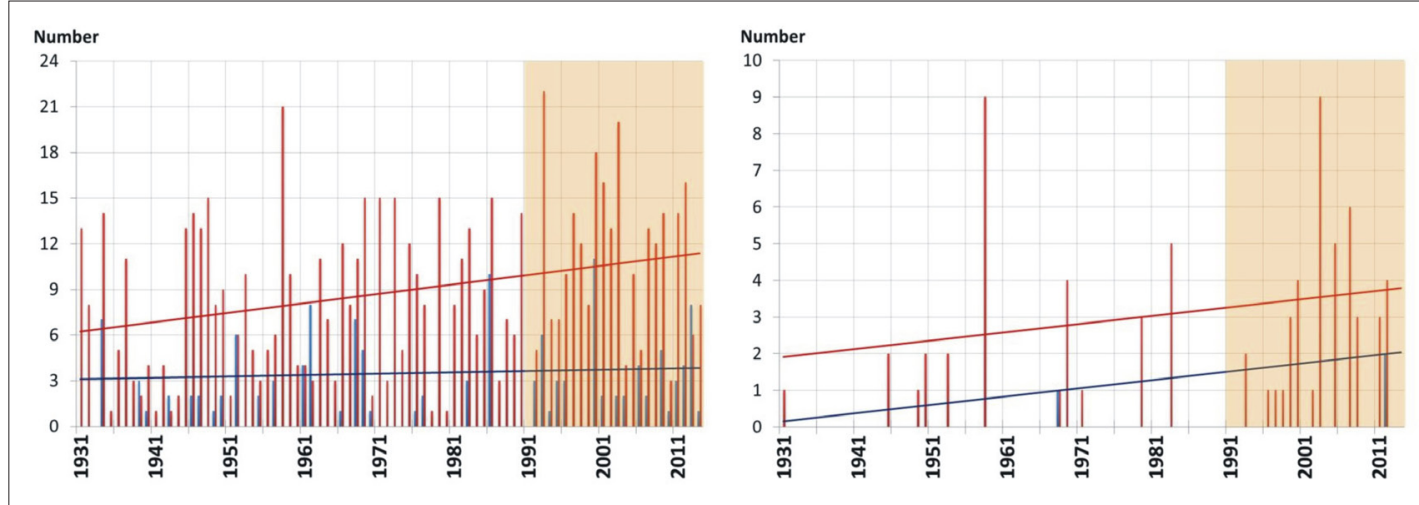

Fig. 4: Number of summer $\left(T_{\max } \geq 25^{\circ} \mathrm{C}\right.$, left $)$ and tropical days $\left(T_{\max } \geq 30^{\circ} \mathrm{C}\right.$, right $)$ in the months of April and May in Hurbanovo since 1931. Source: authors

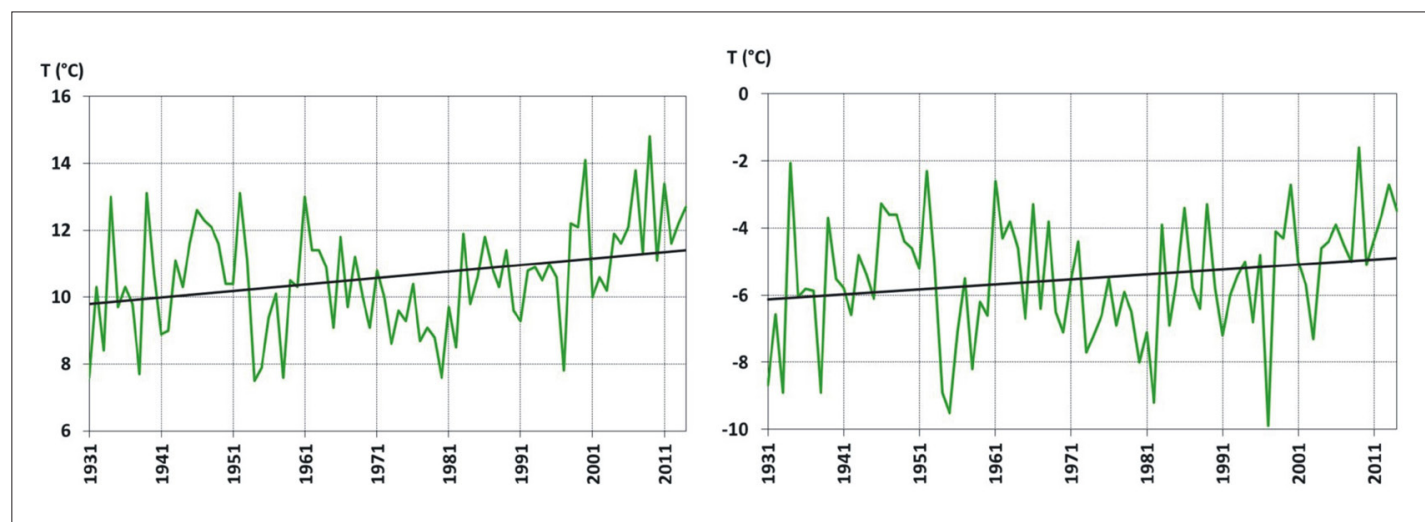

Fig. 5: Average monthly temperatures in April in Bratislava (left) and at Lomnický štít peak (right) in period 1931-2014. Source: authors

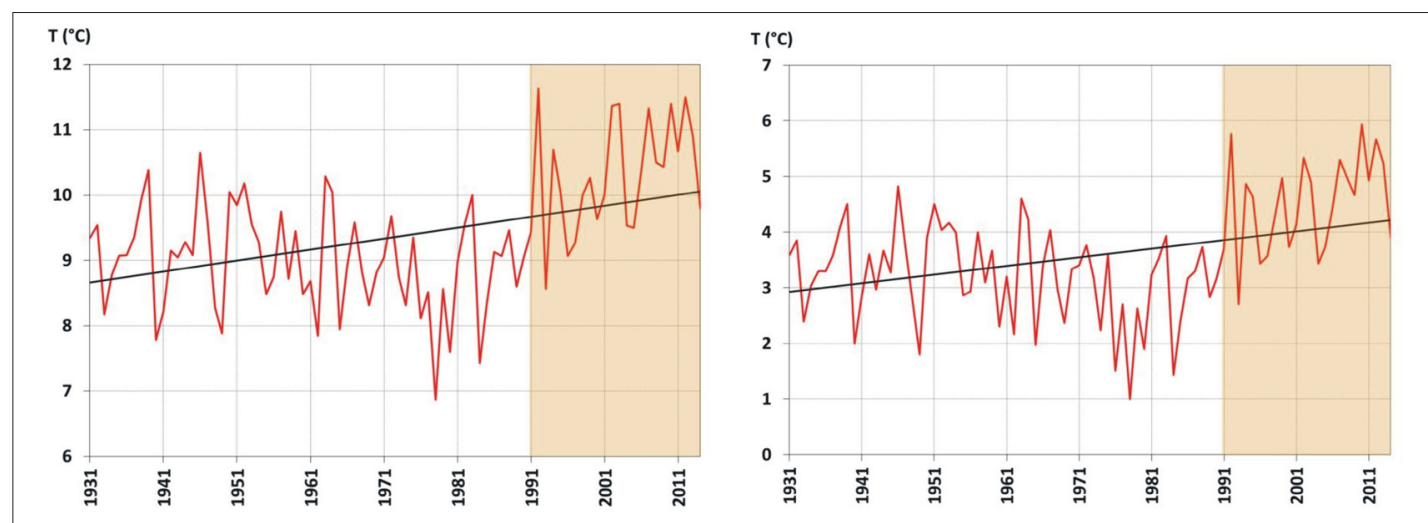

Fig. 6: Average air temperature in summer at Skalnaté pleso lake (left) and at Lomnický štít peak (right) in period 1931-2013. Source: authors

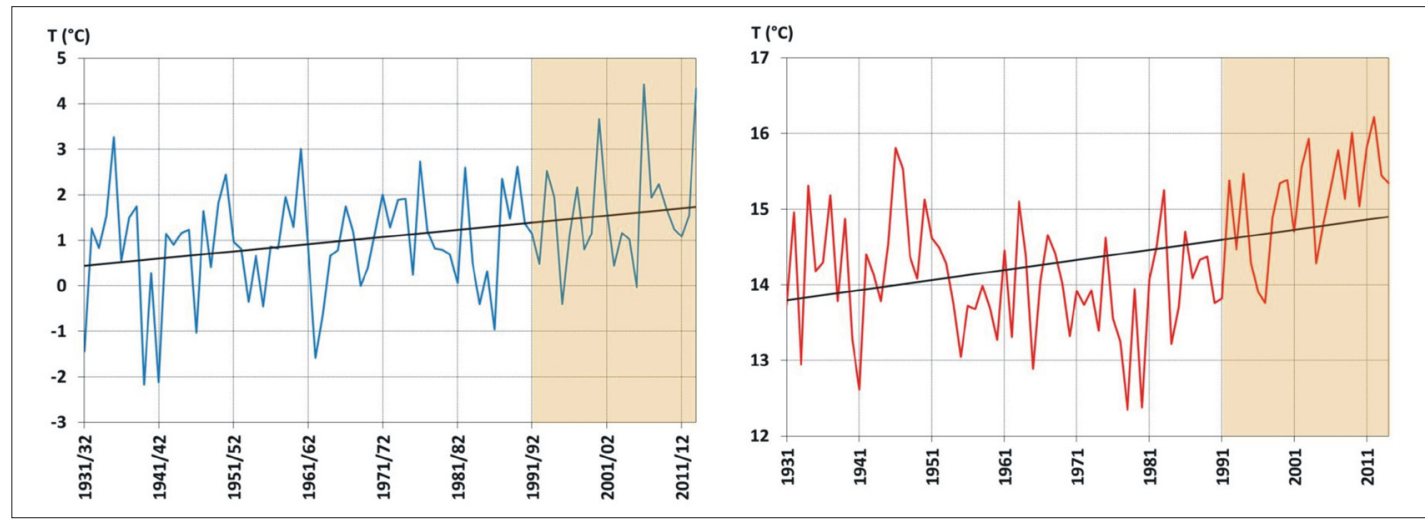

Fig. 7: Spatial average air temperatures in the cold (left) and warm half-year (right) in Slovakia, 1931-2014.

Source: authors 
At the end of $2000 \mathrm{~s}$ and at the beginning of 2010 s, the weather situations which originated in pressure lows over the Mediterranean, participated in precipitation totals in a more important way (Pecho et al., 2010). This situation led to record-breaking annual precipitation in the southern part of Slovakia (Fig. 9). Due to similar synoptic conditions, the winter season in 2012/2013 was characterized by higher precipitation in the southwest of the country and in the southern part of central Slovakia. Some parts of these regions recorded an extraordinary height of snow cover (Matejovič and Pecho, 2013).

From the data presented above, precipitation and air temperature trends are different. Firstly, the precipitation trend is much less notable than the temperature trend.

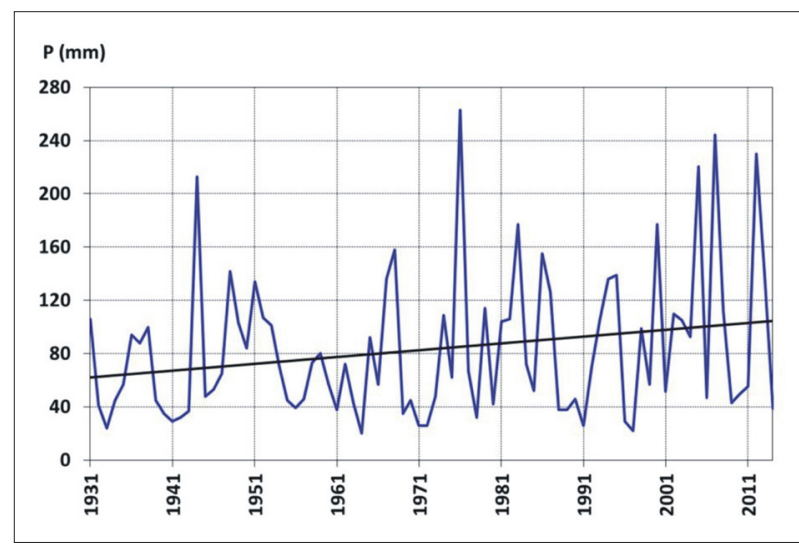

Fig. 8: Monthly precipitation totals in January in Oravská Lesná in the period 1931-2014. Source: authors

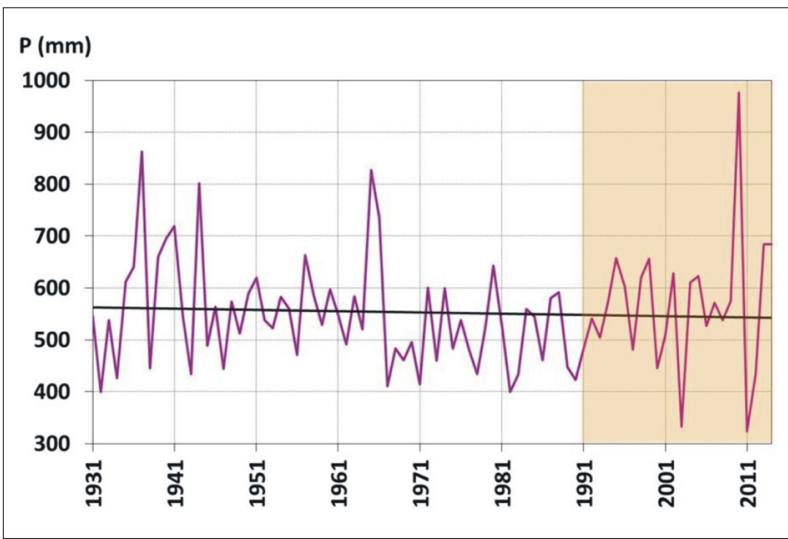

Fig. 9: Annual precipitation total in Hurbanovo in the period 1931-2014. Source: authors

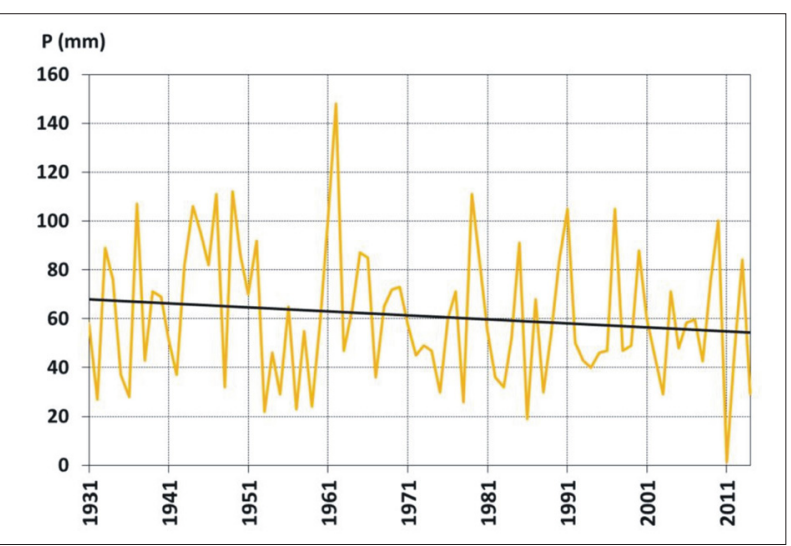

Fig. 10: Spatial precipitation total in Slovakia in November in the period 1931-2014. Source: authors
Precipitation reached a higher intensity during its occurrence compared to the past. It leads to the occurrence of months with extremely below normal and extremely above normal levels of precipitation (Faško, 2012; Faltan et al., 2014). Therefore, the comparison of dry and wet periods seems to be in high contrast. Considering precipitation totals in the reference periods, it might seem that there are no changes, but the annual regime of precipitation has changed.

Considering periods without precipitation or with deficit precipitation, tendencies in precipitation are similar for the whole country, as in the case of air temperature. The spatial extent of these periods has also spread into the traditionally wetter regions of northern and northeastern Slovakia (Matejovič, 2011). As one example, we could mention November 2011, in which extremely low precipitation totals were recorded over the entire country (Fig. 10).

\subsection{Changes in climate regions}

As noted above, Konček and Petrovič (1957) presented a new classification of the climate regions of Czechoslovakia: three main regions - warm, moderately warm and cold. From a comparison of climate regions in Slovakia published in the Landscape Atlas of the Slovak Republic (2002) and in the Climate Atlas of the Slovak Republic (2015), it is obvious that important changes in some regions and sub-regions have occurred. The changes have resulted from two major trends: the increase of monthly average temperature and the drying trend in some regions.

The warm region, earlier established in the Váh river basin up to the town of Ilava, has expanded northward through the Váh river basin and today includes the town of Žilina (Fig. 11). A similar extension of the warm region has appeared in the Hron water basin. These changes are primarily due to warmer conditions in summer, which resulted in a higher number of summer days in these river basins. Both river basins still have enough precipitation in the areas within the extended warm region, which results in Iz values above 60 . Therefore, two new sub-regions occur in Slovakia. The first of them, T8 - warm, humid sub-region with mild winter, is located in the middle part of the Váh river basin. The second sub-region, T9 - warm, humid subregion with cold winter, is recorded northeastward from Kamenica nad Cirochou (northeastern Slovakia) and in the Hron river basin eastward from Banská Bystrica. At these sites, the average monthly temperature in January is still quite low, in contrast to sub-region T8.

The change in temperature conditions, concretely the increase of average monthly temperature in January, results in a change of sub-region in the Východoslovenská nížina lowland (Fig. 12), but also in areas near the towns of Lučenec, Tornal'a and Rimavská Sobota, and in the southern part of the Košická kotlina basin. In these areas, the warm dry sub-region with cold winter (T3) changed to a warm, dry sub-region with mild winter (T2).

The driest sub-region T1 moved northward and it covers the whole of the Podunajská nízina lowland today (Fig. 13), except for the Hronská pahorkatina upland and the Ipel'ská pahorkatina upland. Drying was also identified in the eastern part of the Záhorská nížina lowland, where the warm, moderately humid sub-region $\mathrm{T} 6$ was reclassified into the warm, moderately dry sub-region T4.

The moderately warm region is recorded as a spatial extension at the expense of the cold region. It is the most visible in the Liptov region (located around the towns of 


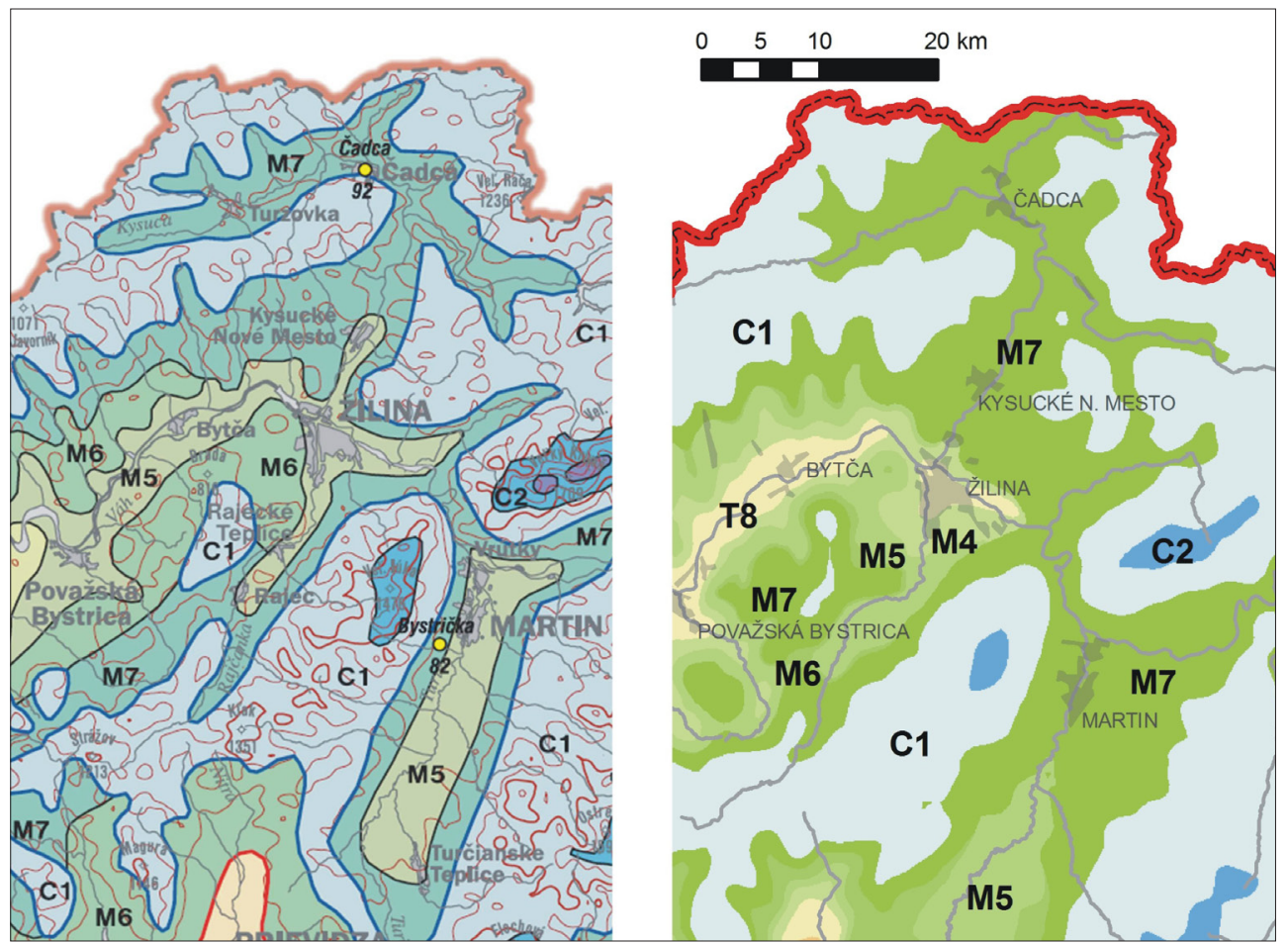

Fig. 11: Climate sub-regions near the town of Žilina in the period 1961-1990 (left), and in the period 1961-2010 (right). Source: Landscape Atlas of the Slovak Republic (2002), authors

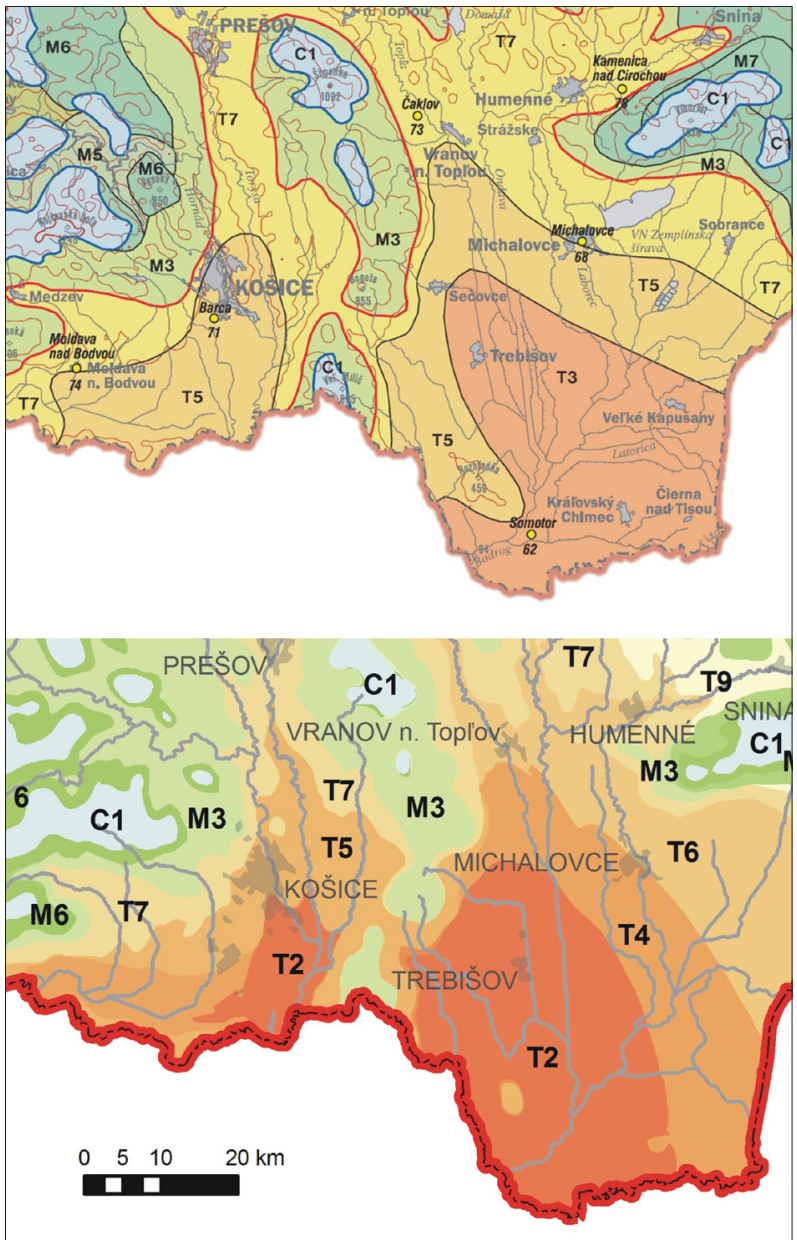

Fig: 12: Climate sub-regions in the Východoslovenská nízina lowland in the period 1961-1990 (top), and in the period 1961-2010 (bottom).

Source: Landscape Atlas of the Slovak Republic (2002), authors
Liptovský Mikuláš and Ružomberok), in the upper part of the Hron river basin, as well as extending northward in the Orava and the Kysuca water basins. The sub-region M2 (moderately warm, moderately humid, with very cold winter) has totally disappeared due to the increase in the average monthly temperature in January. It was located in the Hornádska kotlina basin in the period 1961-1990, but now this area is assigned to the sub-region M3, which is characterised by milder temperature in winter. Some smaller changes due to climate drying are also recorded in the moderately warm region, more concretely in the northeastern part of Slovakia.

The smallest part of Slovakia is classified as "cold region" and it is still shrinking. It is most apparent near the Pil'sko and the Babia hora peaks (the northern part of Slovakia), in the Malá Fatra Mountains, the Vel'ká Fatra Mountains, the Štiavnické vrchy Mountains and the Javorie Mountains. The coldest sub-region, C3, totally disappeared from the Ridge of Malá Fatra Mountains, and is in slow regression in the Tatra Mountains.

\section{Discussion and conclusions}

An analysis of the air temperature characteristics in Hurbanovo (Faško and Švec, 2013) was the impulse for the research reported above: the question was whether similar tendencies exist also in the temperature datasets of other meteorological stations in Slovakia. The trend from the temperature dataset in Hurbanovo was clearly identified in other regions, even in higher altitudes. In this context, an increasing air temperature trend is more notable at high altitudes and in the northern and northeastern part of Slovakia than in its southwestern part in the $21^{\text {st }}$ century. This trend was sharper in the southwest of country at the end of the $20^{\text {th }}$ century (Bochníček et al., 2015). Comparing these results to those from GCMs scenarios for the beginning of $21^{\text {st }}$ century, the temperature trend is in very good agreement with CGCM3.1 (Faško et al., 2009). The same 


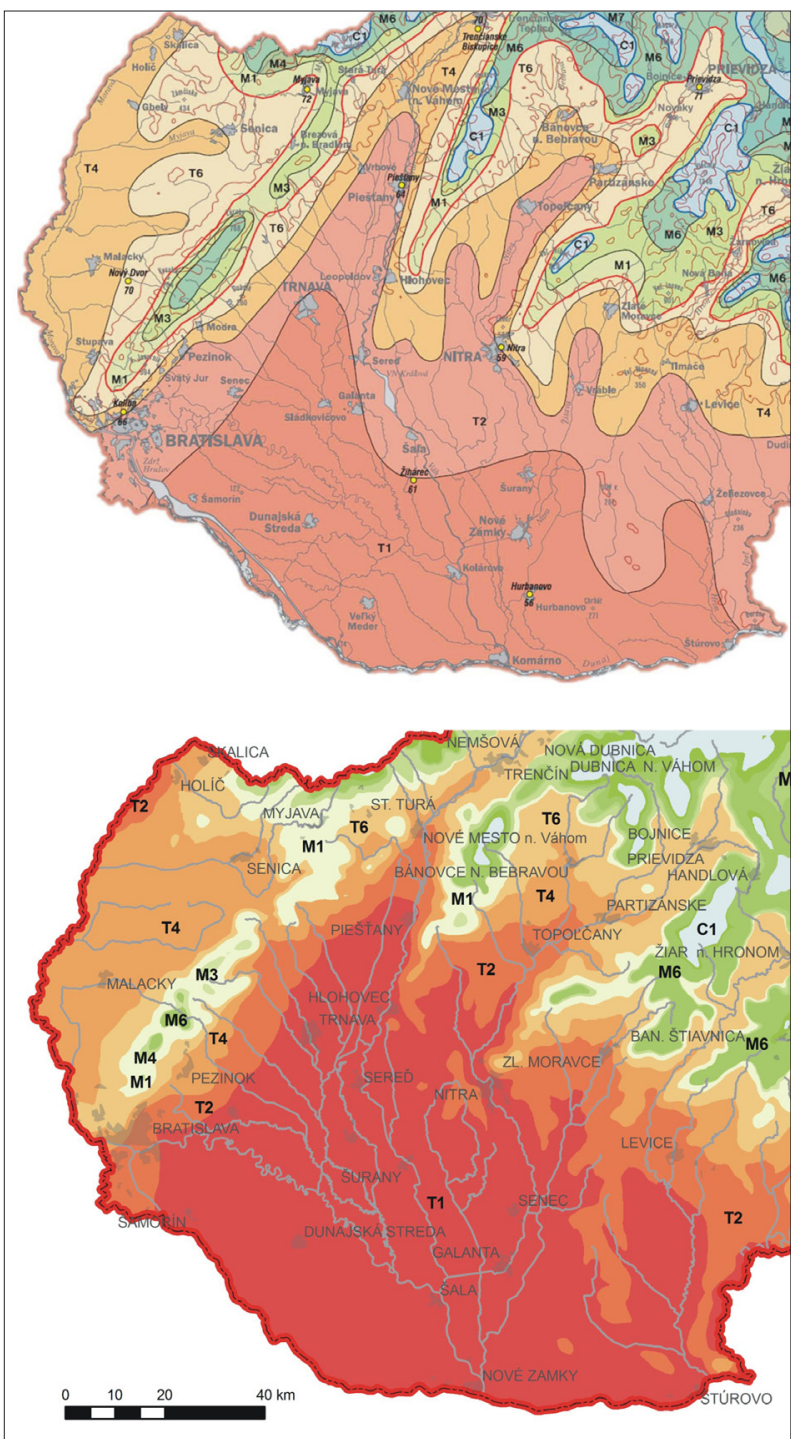

Fig. 13: Climate sub-regions in the Podunajská nížina lowland in the period 1961-1990 (top) and in the period 1961-2010 (bottom). Source: Landscape Atlas of the Slovak Republic (2002), authors

situation is registered by using CCCM 1997, which expected a high temperature increase in summer and smaller in winter (Melo and Lapin, 2000). Our results show that the increase is comparable in these two seasons. On the other hand, a precipitation trend from CGCM2 was not confirmed. A trend that is more similar was reached using GISS 1998, even though the trend in autumn months was not confirmed as well (Faško et al., 2009). All these models were downscaled for Slovakia in 1990s and 2000s.

The precipitation trend is more complex than the temperature trend. It is influenced by particular regional effects, oceanity (or continentality), annual precipitation regime and zonality (or meridionality), in the circulation of air masses bringing precipitation. Overall, changes in precipitation totals and their variability are not as crucial as changes in annual precipitation regime and the contrast variation between wet and dry periods (Faško, 2012).

Even though Konček's moisture index describes moisture conditions in Slovakia very well in the long-term view, the need to modify it is required due to climate change. Modifications are due to the fewer number of days with precipitation, but with higher precipitation intensity at the same time (Melo et al., 2007; Pecho et al., 2008). The result is higher surface runoff, but lower infiltration of water into the soil. Therefore, the water from intense precipitation is less effective for ecosystems. These changes of precipitation regime are not reflected in the results of the index. Another parameter which should be changed is the precipitation surplus above $105 \mathrm{~mm}$ in winter $(\Delta \mathrm{r}>105 \mathrm{~mm})$. Approximately, $60 \%$ of Slovakia has altitudes higher than $300 \mathrm{~m}$ a.s.l., but only $5.4 \%$ of its territory has altitudes higher than $1000 \mathrm{~m}$ a.s.l. In the context of climate change, areas with a persistent snow cover shrink relatively quickly, and occasional snow cover with liquid precipitation in the middle of winter expands over the territory of Slovakia (Lapin and Melo, 2012). Such conditions result in the higher participation of winter precipitation in winter runoff, not in spring runoff as in the past. Therefore, water reserves in spring are low even after winter, which was rich in precipitation. From these findings, the parameter $\Delta \mathrm{r}>105 \mathrm{~mm}$ seems to be unsustainable and should be increased with the increasing average air temperature in winter. Lapin and Melo (2012) suggested to skip this parameter, if average winter temperature is higher than or equal to $2^{\circ} \mathrm{C}$. In other cases, when the average winter temperature is lower than $2{ }^{\circ} \mathrm{C}$, the parameter should vary from $\Delta \mathrm{r}>150 \mathrm{~mm}$ to $\Delta \mathrm{r}>105 \mathrm{~mm}$, according to the temperature (minus $2 \mathrm{~mm}$ for each $0.1^{\circ} \mathrm{C}$ under $2{ }^{\circ} \mathrm{C}$ ).

Despite the fact that modification of Konček's moisture index has not been carried out at present, it is suitable for the assessment of climate changes in Slovakia in such a context. Additionally, it enables the comparison of the results with any earlier published distribution of climate regions in the country. According to the comparison described above, we record the changes in sub-regions due to the increase of average monthly temperature and the drying tendencies in lowlands and surrounding lower parts of Slovakia. These drying tendencies are not caused by the decline of precipitation, but by increasing temperature, which enhances evapotranspiration. These results are in good agreement with Pecho et al. (2008) and Melo et al. (2007b), who identified such drying trends in earlier periods. The changes in the distribution of regions are also due to the increasing air temperature in January, which is most apparent in the south and east of Slovakia. It must be noted that the map of climate regions in the Landscape Atlas (2002) was made without the GIS system and was digitized manually for publication. Therefore, some small differences in climate regions could be the result of different interpolation techniques. On the other hand, this paper presents changes and shifts in climate sub-regions which are clearly not the result of interpolation, but of changes in climate.

\section{Acknowledgment}

This work was part of the project "Development of technology of spatial data processing of the climate system", ITMS 26220220102, which was supported by the Research and Development Operational Programme funded by the European Regional Development Fund.

\section{References:}

BOCHNÍČEK, O., ŠVEC, M., FAŠKO, P., KAJABA, P., ŠŤASTNÝ, P. (2015): Year 2014 - the warmest year in the history of meteorological measurements in Slovakia. Presented at EGU General Assembly 2015, Vienna, $12^{\text {th }}$ $17^{\text {th }}$ April 2015. 
BRÁZDIL, R., BUDÍKOVÁ, M., FAŠKO, P., LAPIN, M. (1995): Fluctuation of maximum and minimum air temperatures in the Czech and the Slovak Republics. Atmospherical Research, 37: 53-65.

BRÁZDIL, R., CHROMÁ, K., DOBROVOLNÝ, P., TOLASZ, R. (2009): Climate fluctuations in the Czech Republic during the period 1961-2005. International Journal of Climatology, 29(2): 223-242.

BRÁZDIL, R., ZAHRADNÍČEK, P., PIŠOFT, P., ŠTEPÁNEK, P., BĚLÍNOVÁ, M., DOBROVOLNÝ, P. (2012): Temperature and precipitation fluctuations in the Czech Republic during the period of instrumental measurements. Theoretical and Applied Climatology, 110(1-2): 17-34.

Climate Atlas of the Slovak Republic (2015). Bratislava, Slovak Hydrometeorological Institute.

FALŤAN, V., JANSKÝ, L., POLČÁK, N., HAZLINGER, M., MADAJOVÁ, M., SLÁDEK, J., BURIAN, L. (2014): Urbanisticko-krajinárska štúdia na ochranu proti prívalovým dažd’om v Malokarpatskej oblasti. Bratislava, Univerzita Komenského.

FAŠKO, P., PECHO, J., MIKULOVÁ, K., ŠŤASTNÝ, P. (2006): Prípady vysokých denných, mesačných a sezónnych úhrnov atmosférických zrážok na východnom Slovensku na konci 20. a na začiatku 21. storočia v kontexte s historickými údajmi. Presented at International Conference "Ochrana pred povodňami", Podbanské, Slovakia, $4^{\text {th }}-7^{\text {th }}$ December 2006.

FAŠKO, P., LAPIN, M., MELO, M., PECHO, J. (2009): Changes in precipitation regime in Slovakia - past, present and future. Presented at $2^{\text {nd }}$ International Conference on Bioclimatology 2009: A changing climate for biology and soil hydrology interactions, Bratislava, Slovakia, 21.-24. September 2009.

FAŠKO, P. (2012): Trendy súčasnej klimatickej zmeny na Slovensku. In: Meteorológia a klimatológia vo vyučovaní, III. Presented at Seminára pre učitelov základných a stredných škôl, Stará Lesná, Slovakia, $13^{\text {th }}-16^{\text {th }}$ June 2012.

FAŠKO, P., ŠVEC, M. (2013): The average monthly, seasonal and annual air temperature in Hurbanovo since 1871. Presented at International Scientific "Conference changes and adaptation strategies", Skalica, Slovakia, $9^{\text {th }}-11^{\text {th }}$ September 2013.

FAŠKO, P., ŠŤASTNÝ, P., ŠVEC, M., KAJABA, P., BOCHNÍČEK, O. (2013): Upward trends in time series of basic characteristics of air temperature at selected meteorological stations in Slovakia. Presented at $13^{\text {th }}$ EMS Annual Meeting \& $11^{\text {th }}$ European Conference on Applications of Meteorology (ECAM), Reading, United Kingdom, $09^{\text {th }}-13^{\text {th }}$ September 2013.

HUNDECHA, Y., BÁRDOSSY, A. (2005): Trends in daily precipitation and temperature extremes across western Germany in the second half of the $20^{\text {th }}$ century. International Journal of Climatology, 25(9): 1189-1202.

CHEVAL, S., BIRSAN, M., DUMITRESCU, A. (2014): Climate variability in the Carpathian Mountains Region over 19612010. Global and Planetary Change, 118: 85-96.

KONČEK, M. [ed.] (1974): Klíma Tatier. Bratislava, Veda SAV. KONČEK, M., PETROVIČ, Š. (1957): Klimatické oblasti Česko-Slovenska. Meteorologické Zprávy, 10(5): 113-119.
Landscape Atlas of the Slovak Republic (2002). Bratislava, Ministry of Environment of the Slovak Republic; Banská Bystrica, Slovak Environmental Agency.

LAPIN, M., NIEPLOVÁ, E., FAŠKO, P. (1995): Regionálne scenáre zmien teploty vzduchu a zrážok na Slovensku. Národný klimatický program, 3/95: 19-55.

LAPIN, M., MELO, M. (1999): Climatic changes and climate change scenarios in Slovakia. Meteorologický časopis, 2(4): 5-15.

LAPIN, M., GERA, M., HRVOL, J., MELO, M., TOMLAIN, J. (2009): Possible impacts of climate change on hydrologic cycle in Slovakia and results of observations in 19512007. Biologia, 64(3): 454-459.

LAPIN, M., MELO, M. (2012): Modifikácia klimatických klasifikácií pre podmienky teplejšej klímy na Slovensku. Meteorologický časopis, 15: 67-74.

LAPIN, M. (2015): Climate change \& climate changes, climate change scenarios [online]. [cit. 16.03.2015] Department of Meteorology and Climatology, Comenius University website. Available at: http://www.dmc.fmph. uniba.sk/public_html/main9.html

MATEJOVIČ, P. (2011): Zima A.D. 1500-2010. História a podoby zím v Európe a na Slovensku. Bratislava, Veda SAV.

MATEJOVIČ, P. (2011): Jeseň 2011. Fórum pre vedu a umenie, December 03, 2011 [online]. [cit. 15.03.2015]. Available at: http://www.nun.sk/jesen2011.htm

MATEJOVIČ, P., PECHO, J. (2013): Klimatologické zhodnotenie zimy 2012/2013. Fórum pre vedu a umenie, March 29, 2013 [online]. [cit. 15.03.2015]. Available at: http:// http://www.nun.sk/zima2013.htm

MELO, M., LAPIN, M. (2000): Teplotné scenáre pre Slovensko založené na výstupoch kanadských klimatických modelov. Geografický časopis, 52(2): 151-165.

MELO, M., LAPIN, M., DAMBORSKÁ, I. (2007a): Končekov index zavlaženia ako možný indikátor aridizačných trendov v krajine. Acta Hydrologica Slovaca, 8(2): 224-230.

MELO, M., LAPIN, M., DAMBORSKÁ, I. (2007b): Detection of climatic trends and variability at Hurbanovo. In: Střelcová, K., Škvarenina, J., Blaženec, M. [eds.] (2007): "Bioclimatology and natural hazards". Presented at International Scientific Conference, Pol'ana nad Detvou, Slovakia, September 12.-20. 2007.

MELO, M., KRUŽICOVÁ, A. (2011): Konček climate shifts in the Tatra Mts. between periods 1951-1980 and 19812010. In: Šiška, B.,Hauptvogl, M., Eliašová, M. [eds.]: Bioclimate: Source and Limit of Social Development. Presented at International Scientific Conference, Topol'čianky, Slovakia, $6^{\text {th }}-9^{\text {th }}$ September 2011.

NIEDZWIEDZ, T., TWARDOSZ, R., WALANUS, A. (2009): Long-term variability of precipitation series in east central Europe in relation to circulation patterns. Theoretical and Applied Climatology, 98(3-4): 337-350.

PECHO, J., FAŠKO, P., MIKULOVÁ, K., LAPIN, M., ŠŤASTNÝ, P. (2009): Long-term changes of snow cover regime in connection with observed solid, liquid and mixed precipitation ratio trends in Slovakia. Presented at $9^{\text {th }}$ Annual Meeting of the European Meteorological Society, Nineth European Conference on Applied Meteorology (ECAM), Toulouse, France, $28^{\text {th }}$ September- $2^{\text {nd }}$ October. 
PECHO, J., FAŠKO, P., LAPIN, M., KAJABA, P., MIKULOVÁ, K., ŠŤASTNÝ, P. (2010): Extrémne atmosférické zrážky na jar a na začiatku leta 2010 na Slovensku. Meteorologický časopis, 13: 69-80.

PECHO, J., FAŠKO, P., MELO, M. (2008): Precipitation deficit periods in the Danubian lowland in Slovakia. Presented at XXIV ${ }^{\text {th }}$ Conference of the Danubian Countries on the Hydrological Forecasting and Hydrological Bases for Water Management, Bled, Slovenia, $2^{\text {nd }}-4^{\text {th }}$ June 2008.

PECHO, J., FAŠKO, P., MIKULOVÁ, K., ŠŤASTNÝ, P., NEJEDLÍK, P., KOŠŤÁLOVÁ, J. (2010a): Comparative analysis of selected snow cover characteristics in Slovakia within the 1950/1951-1979/1980 and 1980/1981-2009/2010 winters. Presented at $7^{\text {th }}$ EGU General Assembly, Vienna, $2^{\text {nd }}-7^{\text {th }}$ May 2010.

PECHO, J., FAŠKO, P., MIKULOVÁ, K., ŠŤASTNÝ, P., NEJEDLÍK, P., KOŠŤÁLOVÁ, J. (2010b): Comparative spatial and statistical analysis of selected snow cover climatological characteristics (SC duration) in Slovakia within the 1950/1951-1979/1980 and 1980/19812009/2010 winters. Presented at $10^{\text {th }}$ Annual Meeting of the European Meteorological Society, Eighth European Conference on Applied Climatology (ECAC), Zürich, Switzerland, $13^{\text {th }}-17^{\text {th }}$ September 2010.

PETROVIČ, Š., ŠOLTÍS, J. (1984): Zborník prác SHMÚ č. 23. Bratislava, Slovak Hydrometeorological Institut.

PIŠOFT, P., KALVOVÁ, J., BRÁZDIL, R. (2004): Cycles and trends in the Czech temperature series using wavelet transforms. International Journal of Climatology, 24(13): 1661-1670.
SOBÍŠEK, B. [ed.] (1993): Meteorologický slovník výkladový a terminologický. Praha, Academia.

SPINONI. J., SZALAI, S., SZENTIMERY, T., LAKATOS, M., BIHARI, Z., NAGY, A., NÉMETH, A., KOVÁCS, T., MIHIC, D., DACIC, M., PETROVIC, P., KRIŽIČ, A., HIEBL, J., AUER, I., MILKOVIC, J., ŠTEPÁNEK, P., ZAHRADNÍČEK, P., KILAR, P.,LOMANOWKA, D.,PYRC, R., CHEVAL, S., BIRSAN, M. V., DUMITRESCU, A., DEAK, G., MATEI, M., ANTOLOVIC, I., NEJEDLÍK, P., ŠŤASTNÝ, P., KAJABA, P., BOCHNÍČEK, O., GALO, D., MIKULOVÁ, K., NABYVANETS, Y., SKRYNYK, O., KRAKOVSKA, S., GNATIUK, N., TOLASZ, R., ANTOFIE, T., VOGT, J. (2014): Climate of Carpathian Region in the period 1961-2010: climatology and trends of 10 variables. International Journal of Climatology, 35(7): 1322-1341, DOI: 10.1002/joc.4059.

SZENTIMREY, T. (2003): Homogenization software MASHv3.03 [online] [cit. 14.10.2014]. Hungarian Meteorological Service Available at:http://www.met.hu/ en/omsz/palyazatok_projektek/carpatclim/

ŠAMAJ, F., VALOVIČ, Š. (1982): Priestotové úhrny zrážok na Slovensku (1881-1980). Meteorologické zprávy, 4: 108-118.

THORNTHWAITE, C. W. (1948): An approach toward a rational classification of climate. Geographical Review, 38: 55-94.

TWARDOSZ, R., LUPIKASZA, E., NIEDWIEDZ, T., WALANUS, A. (2012): Long-term variability of occurrence of precipitation forms in winter in Krakow, Poland. Climatic Change, 113(3-4): 623-638.

VÝBERČI, D. (2012): Vlny horúčav na Slovensku v období 1951-2010 a ich dopady na úmrtnost’ od roku 1996 (Master thesis). Bratislava, Univerzita Komenského.

Initial submission 27 November 2014, final acceptance 23 June 2015

Please cite this article as:

LABUDOVÁ, L., FAŠKO, P., IVAŇÁKOVÁ, G. (2015): Changes in climate and changing climate regions in Slovakia. Moravian Geographical Reports, 23(3): 70-81. DOI: 10.1515/mgr-2015-0019. 